\title{
Impact of COVID-19 on Christmas
}

\author{
Gary P. Wormser
}

Received: 17 September 2020 / Accepted: 22 October 2020 / Published online: 30 October 2020

(c) Springer-Verlag GmbH Austria, part of Springer Nature 2020

\section{Letter to the editors}

\section{Dear Editors,}

Although of course not known for certain, it is likely that COVID-19 will still exist in December 2020 potentially impacting a variety of activities relating to Christmas in the USA and worldwide, including parties, shopping for gifts and attending church services. However, let's not forget Santa Claus. Santa Claus is not young and appears to be a bit overweight, likely from all the milk and cookie treats he consumes each Christmas. Therefore, he may be at greater risk for more severe illness if he develops COVID-19 infection. Does Santa even have a health care provider?

Under usual circumstances, Santa Claus would be expected to enter millions of homes to bring the presents the families so badly need and desire (over 36 million homes in the USA alone estimates show [1]).

So there are multiple issues and questions. Should Santa enter homes in which a person with COVID19 is residing or should those residences be excluded? Should Santa require documentation of recent negative COVID-19 RNA testing of all persons living in each home to decide if it is safe to enter? If so, how would that information be conveyed to Santa? Would the results be placed on the top of the chimney? How would Santa make it clear that such testing was even required? Even if all persons residing in a home tested negative, however, that does not completely exclude that someone there is infected. Perhaps an even more

\section{G. P. Wormser, M.D. ( $ه)$}

Division of Infectious Diseases, New York Medical College, 40 Sunshine Cottage Road, Skyline Office \#2N-E14, Valhalla, NY, USA

gwormser@nymc.edu fundamental question, is it really fair or appropriate to exclude homes in which people are suffering from COVID-19? The people in such homes are more in need of Santa than ever.

When entering homes in either scenario, should Santa wear a face mask to protect against inhaling the virus? If so, should it be an N95 mask or just a surgical mask? That question is easy to answer since Santa's beard would preclude proper fit testing for the N95 mask. Should he wear a face shield? Santa will be touching the Christmas stockings and the plates with the cookies and the glasses with the milk left for him in the USA. Should he wear gloves and put on new gloves for each home he visits? Should he use hand sanitizer after each visit? Should he be concerned about fecal-oral spread to him of COVID-19 when he consumes the snack left for him, a highly controversial and unlikely mode of transmission? Will Santa potentially contaminate household objects with COVID-19 picked up in one home and then brought to other homes? Indeed, might this consideration make some families hesitant to have Santa visit this year?

A more practical issue is whether Santa will even be allowed to travel across countries or across state lines in the USA. Or will he be required to self-quarantine for 14 days when traveling from say Florida to New York State? In addition, will Santa be required to test negative for COVID-19 RNA on 23 December 2020 in order to begin his journey? Does COVID-19 testing even exist on the North Pole?

Should Santa not enter homes in 2020 at all but instead deliver the gifts to the curbside (i.e., curbside delivery)? Or should Santa contract out with a professional delivery organization to deliver his presents this year? Should Santa's visit be virtual rather than in-person, with presents instead delivered by mail? Whether using a professional delivery service or the regular mail, there will be financial costs not incurred 
in previous years. Does Santa have the funds to pay for these services? Or should Christmas just be postponed?

The questions raised above with regard to COVID19 are all important with direct relevance to the Christmas tradition and to the wellbeing of Santa Claus, and as well to the happiness and emotional wellbeing of the families hoping to have Santa make his annual visit. The World Health Organization and the Centers for Disease Control and Prevention need to weigh in on this, and perhaps the leadership of each of the countries and states where Santa would be expected to visit. December 24th is not that far away, so we need to have guidance on these issues as soon as possible.

Assuming there is no official guidance, I would like to offer the approach that I think is clearly the most appropriate. My recommendations are based in part on the fact that December is also influenza season in the Northern Hemisphere [2]. However, with regard to influenza, a virus with similar modes of transmission to COVID-19, I am unaware of any data that would suggest that Santa Claus ever became ill from influenza or ever transmitted influenza to others during any prior Christmas. Therefore, I do not believe that Santa Claus will be at risk for either acquiring or transmitting COVID-19. In my opinion, Santa Claus should make his visits in an identical fashion to that which he has done in prior years.

Acknowledgements The author thanks Joan Wormser for assistance.

Conflict of interest G.P. Wormser Wormser reports receiving research grants from Immunetics, Inc., Institute for Systems Biology, Rarecyte, Inc., and Quidel Corporation. He owns equity in Abbott/AbbVie; has been an expert witness in malpractice cases involving babesiosis and Lyme disease; and is an unpaid board member of the American Lyme Disease Foundation.

\section{References}

1. Wormser GP, Ladenheim A. How many calories did Santa Claus consume on Christmas Eve? Wien Klin Wochenschr. 2018;130:73-5.

2. Wormser GP. COVID-19 versus seasonal influenza 20192020: USA. Wien Klin Wochenschr. 2020;132:387-9.

Publisher's Note Springer Nature remains neutral with regard to jurisdictional claims in published maps and institutional affiliations. 